\title{
LEGISLAC̣ÃO
}

\section{O Novo substitutivo da Constituição e o Servidor Público}

\section{Capítulo VII da Administração Pública Seção I Disposições Gerais}

Art. 43 - A administração pública, direta ou indireta, de qualquer dos poderes, obedecerá aos princípios da legalidade, impessoalidade, moralidade e publicidade, exigindo-se, salvo na hipótese de recisão do contrato de trabalho, como condição de validade dos atos administrativos, a motivação suficiente e, como requisito de sua legitimidade, a razoabilidade.

$\S 10$ - Nenhum ato da administração pública imporá limitação, restrição ou constrangimento, salvo se indispensável para atender a finalidade da lei.

§ 2: - A apreciação das reclamações relativas à prestação de serviços públicos será disciplinada em lei, que preverá as medidas administrativas e disciplinares cabiveis.

$\S 30^{\circ}-$ Os atos de improbidade administrativa importarāo na suspensāo dos direitos políticos, na perda de função pública, na indisponibilidade dos bens e no ressarcimento ao erário, na forma e gradação previstas em lei, sem prejuizo da ação penal correspondente.

$\S 40^{\circ}-$ A lei estabelecerá os prazos de prescrição para ilícitos praticados por qualquer agente, servidor ou não, que causem prejuizos ao erário, ressalvadas as respectivas ações de ressarcimento, que serāo imprescritiveis.

$\S 50^{\circ}-$ A revisão geral da remuneraçảo dos servidores públicos civis e dos militares far-se-á sempre na mesma época.

$\S 6^{\circ}$ - A lei fixará a relação de valores entre a maior e a menor remuneração da administração pública, direta ou indireta, observados, como limites máximos e no âmbito dos respectivos poderes, os valores percebidos como remuneração, em espécie, a qualquer título, por membros do Congresso Nacional, Ministros do Supremo Tribunal Federal e Ministros de Estado e seus correspondentes nos Estados e Municípios.
$\S 7$ : $^{\circ}$ É vedada qualquer diferença de vencimento entre cargos e empregos iguais ou assemelhados dos servidores dos poderes Legislativo, Executivo e Judiciário, ressalvadas as vantagens de caráter individual e as relativas à natureza ou ao local de trabalho.

$\$ 8^{\circ}$ - Salvo em virtude de concurso público, o cônjuge e o parente até segundo grau, em linha direta ou colateral, consanguíneo ou afim, de qualquer autoridade, não pode ocupar cargo ou função de confiança, inclusive sob contrato, em organismos a ela subordinados, na administração pública.

$\S 9^{\circ}-$ As pessoas jurídicas de direito público e as de direito privado prestadoras de serviços públicos responderão pelos danos que seus agentes, nesta qualidade, causarem a terceiros, assegurado o direito de regresso contra o responsável nos casos de dolo ou culpa.

$\S 10$ - É vedada a vinculação ou equiparação de qualquer natureza, para o efeito de remuneração do pessoal do serviço público, ressalvado o disposto no parágrafo $6^{\circ}$ deste artigo.

$\S 11$ - É vedada a acumulação remunerada de cargos, empregos e funções públicos, exceto nos casos previstos em lei complementar, obedecidos os critérios de compatibilidade de horários e correlação de matérias.

$\S 12$ - A proibição de acumular a que se refere o $\S 11$ estende-se a cargos, empregos e funçōes em autarquias, empresas públicas, sociedades de economia mista e fundações públicas.

$\S 13$ - Os acréscimos pecuniários percebidos por servidor público, não serão computados nem acumulados, para fins de concessão de acréscimos ulteriores, sob o mesmo titulo ou idêntico fundamento.

$\S 14$ - Aplica-se à administração pública em geral o disposto no $\S 3^{\circ}$. do artigo $7{ }^{\circ}$, na condição de contratante ou contratada.

\section{Seção II dos Servidores Públicos Civis}

Art. 44 - Os cargos, empregos e funçōes públicos são acessíveis aos brasilei- ros que preencham os requisitos estabelecidos em lei.

$\S 1^{\circ}$ - A primeira investidura em cargo ou emprego público, sob qualquer regime, dependerá sempre de aprovação prévia em concurso público de provas ou de provas e títulos.

§ 2. - A União, os Estados, o Distrito Federal e os Municipios instituirão, no âmbito de sua competência, regime juridico único para os servidores da administração pública direta e autarquias, bem como plano de carreira.

§ 3. - São estáveis, após dois anos de efetivo exercício, os servidores nomeados por concurso público. Extinto o cargo ou declarada a sua desnecessidade, o funcionário estável ficará em disponibilidade remunerada, até seu adequado aproveitamento em outro cargo.

§ 4..$^{\circ}$ - Será convocado para assumir seu cargo ou emprego aquele que foi aprovado em concurso público de provas e títulos, com prioridade sobre novos concursados, na carreira. A convocação será por edital e fixará prazo improrrogável.

$\S 5^{\circ}$ - - Os cargos em comissão e funçōes de confiança na administração pública serão exercidos, preferencialmente, por servidores ocupantes de cargo de carreira técnica ou profissional, nos casos e condições previstos em lei.

$\S 6^{\circ}$ - Sào assegurados ao servidor público civil o direito à livre associação sindical e o de greve, observado o disposto nos artigos $9^{\circ}$ e 10 desta constituição.

$\S 7^{\circ}$ - Aplica-se, ainda, aos servidores da administração pública o disposto nos incisos IV, V, VI, VII, VIII, X, XI, XIII, XIV, XV, XVI, XVIII e IXI do artigo 6: desta constituição.

Art. 45 - O servidor será aposentado:

I - por invalidez;

II - compulsoriamente, aos setenta anos;

III - voluntariamente, após trinta e cinco anos de serviço para o homem e trinta para a mulher.

$\S 1$. - Não haverá aposentadoria em cargos, funçōes ou empregos temporários.

$\S 20^{\circ}$ - Lei complementar poderá estabelecer exceçōes ao disposto no "caput" deste artigo, no caso de exercício de ati- 


\section{LEGISLAC̣ÃO}

vidades consideradas penosas, insalubres ou perigosas.

Art. 46 - Os proventos da aposentadoria serão:

I - integrais, quando o servidor:

a) contar com o tempo de serviço exigido, na forma do disposto no artigo anterior;

b) sofrer invalidez permanente, por acidente em serviço, moléstia profissional ou doença grave, contagiosa ou incurável, especifica em lei;

II - proporcionais ao tempo de serviço, nos demais casos.

Art. 47 - Os proventos da inatividade e as pensōes serão reajustados, na mesma proporção e na mesma data, sempre que se modificar a remuneração dos servidores em atividade.

Parágrafo único - $O$ benefício de pensão por morte equivalerá a cinqüenta por cento da remuneração ou dos proventos do servidor público falecido, acrescido de dez por cento por dependente econômico, até o limite da remuneração ou dos proventos.

Art. 48 - Ao servidor público em exercício de mandato eletivo, aplicam-se as disposições seguintes:

I - tratando-se de mandato eletivo federal ou estadual, ficará afastado de seu cargo, emprego ou função, sem direito a optar pela sua remuneração;

II - investido no mandado de Prefeito ou de Vereador, será afastado de seu cargo, emprego ou função, sendo-lhe facultado optar pela sua remuneração.

Art. 49 - O servidor público estável só perderá o cargo em virtude de sentença judicial, ou mediante processo administrativo no qual the seja assegurada ampla defesa.

Parágrafo único - Invalidada por sentença a demissão, o servidor será reintegrado e eventual ocupante da vaga reduzido ao cargo de origem, sem direito a indenização, ou aproveitado em outro cargo, ou, ainda, posto em disponibilidade.

\section{Seção III Dos Servidores Públicos Militares}

Art. 50 - As patentes, com as prerrogativas, os direitos e deveres a elas inerentes, são asseguradas em toda a plenitude aos oficiais da ativa, da reserva ou reformados, das Forças Armadas, das policias militares e dos corpos de bombeiros dos Estados, dos Territórios e do Distrito Federal, sendo-lhes privativos os títulos, postos e uniformes militares.

$\$ 1$ : - São servidores militares os integrantes das Forças Armadas, das polícias militares e dos corpos de bombeiros militares dos Estados, Territórios e Distrito Federal.

$\S 2$ : - O militar em atividacie que aceitar cargo público civil permanente será transferido para a reserva.

\& $3^{\circ}$ - - O militar da ativa que aceitar cargo, emprego ou função pública temporária, não eletiva, inclusive da administração indireta, ficará agregado ao respectivo quadro e somente poderá ser promovido por antigüidade, enquanto permanecer nessa situação, contando-se-lhe o tempo de serviço apenas para aquela promoção e transferência para a reserva. Depois de dois anos de afastamento, contínuos ou não, será transferido para a inatividade.

§ 4: - Ao militar são proibidas a sindicalização e a greve.

$\S 50^{\circ}-$ Os militares, enquanto em efetivo serviço, não poderão estar filiados a partidos políticos.

$\$ 6^{\circ}$ - O oficial das Forças Armadas só perderá o posto e a patente se for julgado indigno do oficialato ou com ele incompatível, por decisão de Tribunal Militar de caráter permanente, em tempo de paz, ou de um Tribunal Especial em tempo de guerra.

$\$ 70^{\circ}-\mathrm{O}$ oficial condenado por tribunal civil ou militar a pena restritiva da liberdade individual, superior a dois anos, por sentença condenatória transitada em julgado, será submetido ao julgamento previsto no parágrafo anterior.

$\S 8^{\circ}$ - A lei estabelecerá os limites de idade e outras condições de transferência do servidor militar para a inatividade.

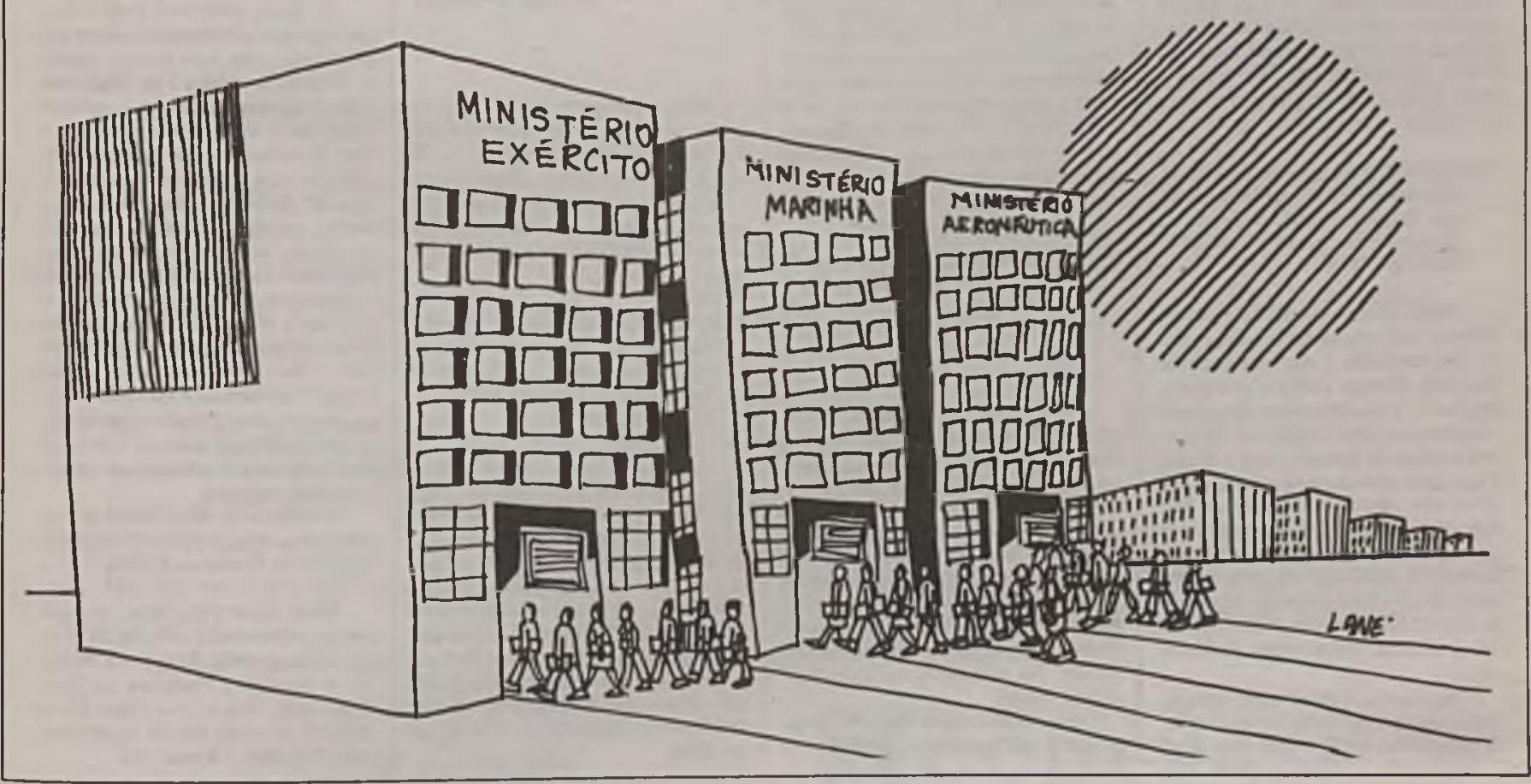

